\title{
The Economic and Financial Crimes Commission and Corruption Management in Nigeria: a Perceptual Assessment of its Legal Framework
}

\author{
Hassan Said Umar and Kasim Umar* \\ University of Abuja \\ P.M.B 118, Permanent Site, Airport Road, Abuja-FCT
}

Received 14.09.2015, received in revised form 22.10.2015, accepted 03.02.2016

The menace of corruption and the fight against it the world wide has been a major preoccupation amongst pundits and administrators, especially amongst the third world countries. The existence of Anticorruption Agencies virtually in all countries of the world justifies this assertion. While some of these agencies in their countries of operations succeed others are still grabbling with the dynamics and complexities of the scourge thus looking for a durable methodology to curtail it spread. This paper assessed the perception of Nigerian on the strength of the EFCC against its functional responsibilities to determine the adequacy and appropriateness of the powers. The research is a survey type that explored both primary and secondary sources. The primary data were gathered through administration of questionnaire with a content analysis for the secondary data. Relying on Structural Functional theory, the study reveals among other things that, EFCC lacks adequate prosecutorial powers; it also cannot effectively ensure and monitor compliance to the limit of foreign currency transfer (\$10000) and the local cash transaction limit; the court system in Nigeria has also frustrated the efforts of the commission in addition to the unruly behaviour of some senior legal counsels who often connive with some judges to subvert justice. The paper therefore submits that the EFCC operate within unfavourable legal space that hinders to a large extent its operational success. It is therefore recommended inter alia: a specialised and separate court with specialised judges to handle financial crimes, streamlining the areas of responsibilities to just financial crimes for the EFCC.

Keywords: Corruption, EFCC, Function, Legal Framework.

DOI: 10.17516/1997-1370-2016-9-2-310-317.

Research area: sociology, politology.

\subsection{Introduction}

Public organisations the world over operate within the confines of the enabling laws establishing them. The operational impact and or success of such organisations definitely will be weighed within the latitude and space accorded them under the law. The fight against corruption in Nigeria has widely been perceived as not effective because the ugly incidence remains continuously unabated. The apparent failure to rid the country of corruption through the Anti Corruption Agencies (ACAs) has over the years been attributed to so many factors amongst which is the financial base of the agencies, leadership

C) Siberian Federal University. All rights reserved

* Corresponding author E-mail address: hassbanna@yahoo.com, kasim.umar@rocketmail.com 
and the political atmosphere within which they operate. But, of greater concern to governance analysts, administration pundits and academics is the legal framework within which the Anti Corruption Agencies (ACAs) are allowed to operate in Nigeria. Amongst the Anti graft agencies in Nigeria, most prominent of them on the lips of contemporary Nigerians is the Economic and Financial Crimes Commission (EFCC). The EFCC has been in an active fight against corruption for more than a decade now but the effectiveness and/ or success is considered to have fallen below expectations. Some researchers, most especially Sa'id, (2014) attributed the ineffectiveness to the earlier factors mentioned as finance, leadership, political atmosphere and ethical factors such as corruption within the operatives. Beyond these factors is the legal framework within which this all- important anti corruption agency (EFCC) operates. Since it has been argued that operational success of such organisations is to a large extent connected to the legal space they enjoy, it is therefore imperative to evaluate the legal framework within which the EFCC performs its functions. This will no doubt expose the scope and limit of its operations and therefore provides an avenue for intellectual assessment of its success against the available powers.

This research is concerned with the operational powers and/ legal frame of the EFCC; this is to allow for a more articulate opinion as to whether the commission is properly positioned with the necessary and adequate powers to be effective. To do this therefore, there is need to ask among other specific questions as whether the EFCC has adequate powers of prosecution. Secondly, does the commission has the capacity to control or monitor transfer of foreign currencies across Nigerian boarders? Thirdly, how effective is the commission on the fight against Drugs and narcotics? Fourthly,
Can EFCC regulate and control daily cash limit transactions as required by the law establishing it. Fifthly, do the proceedings in the regular courts frustrate the efforts of the EFCC? The last is to what extents does corruption amongst the lead counsels affect the functions of the EFCC? These are some of its functional responsibilities as provided by the prohibition act, 2006 as amended. It is therefore against these outlined functions that the commission's effectiveness can be objectively assessed. The research therefore seeks to assess the operations of the EFCC along these areas of responsibilities against the enabling space of powers.

\subsection{Theoretical issues}

The concept of corruption has been greatly overstretched in the academic circle and so the assessment of the anti corruption agencies. The scourge has been viewed with different phases and extents depending on the context, the society and time. The common ground however in all conceptions and contexts has been that corruption and/or any act perceived to be corruption is an evil inclination which diametrically negates human and societal development.

Andvig, (2001) sees corruption as largely a clandestine or concealed practice with strong normativeundertonessimilartootherphenomenon like large scale and petty crime, parallel to black market activities and drug marketing.

When making a house-cleaning, one will have to start from the upper stories and shove the trash towards the ground floor. Likewise, the fight against corruption will have to start at the highest levels of the start (Andvig et al, 2001).

An anti-corruption agency on the other hand is a publicly funded body of a lasting nature with a specific mission to fight corruption and reduce opportunities for corruption by means of prevention and repression strategies (Meagher and Voland, 2006). Although, arguments abound 
that democratisation will nevertheless have to be supported by strengthening the democratic institutions in order to work against corruption. This implies efficient mechanisms of control, detection and punishment (what has been called watchdog bodies). Except for the few instances in which efficient control is based on authoritarian (totalitarian) rule, the different watchdog bodies will have to be independent institutions that can survey, report, arbitrate, judge, and enforce. Besides, democratisation will in addition to the establishment and independence of these institutions and practices, also imply a prior democratic institutionalization of a larger set of relatively balanced social forces, of politically countervailing powers.

\section{2.b. Determinants}

of an Effective Anti-corruption Agency

How well ACA's actually carry out their tasks and what impact this has on corrupt activities according to Heilbruun, (2004) depends on many factors. These include the political mandate of the ACA, the scope of its power and jurisdiction, its resource base and management, its structural setting and safeguards and external factors such as general governance quality and macroeconomic stability.

An ACA's main contributions should be synergy, coordination, concentrated power and autonomy. Thus, the policy rationale for establishing an ACA would be that, unlike existing agencies of oversight and enforcement, the ACA:

i. Will not itself be tainted by corruption or political intrusion;

ii. Will resolve coordination problems among multiple agencies; and

iii. Will centralize all necessary information and intelligence about corruption and assert leadership in the anticorruption effort.
This suggests that the main expected outcome of an ACA should be an overall improvement in the performance of the range of existing anticorruption functions within already established government institutions, not the addition of new activities or use of the ACA to substitute for functions that should be performed by other parts of government

\section{2.c. General Principles \\ and Characteristics of $A C A$}

Anti-corruption agencies are different from other bodies with which they share competences due to the following general principles and characteristics:

\section{a. Independence}

Independence is a key issue in the design of this type of public body. Most discussions on ACAs revolve around this problem. Independence must be regarded not as irresponsibility or absence of reporting or external control but as the capacity to carry out its mission without political interference. As bodies responsible for implementing a national anti-corruption policy or strategy, ACAs are not completely “independent”. The concept is therefore linked to other guiding principles such as impartiality, objectivity, fairness, accountability, a clear, legally defined remit and, above all, structural or operational autonomy.

\section{b. Specialisation}

The fight against corruption today requires an articulated, multidisciplinary, informed strategy. It is no longer a question of corruption as an exchange between two individuals (passive and active). The growing complexity of the phenomenon can be seen in the nature of the players, the types of exchange, the settings in which they occur and the sophistication of transaction mechanisms. This therefore calls for 
a more deliberate and specialised set of efforts that may include a special court and judges for corruption cases. This is because the nature and activities of the regular courts especially in Nigeria will hinder considerably the smooth and fast prosecution of offenders. The delays and technicalities inherent in the Nigerian regular courts have been points of reference for the failure of the EFCC. This has also been confirmed by the immediate past chairman of the commission when he lamented (Daily post, 2012) that amongst other problems associated with courts in Nigeria that

"We have example of a case we charged to court in 2006; for this very case, we have gone to the Supreme Court twice on just interlocutory applications. They will file this, the judge will overrule them, they will go to Court of Appeal and lose there, but they will still go to the Supreme Court. At Supreme Court when they lose, they will be asked to go to the trial judge for the case to continue".

\section{c. Wide Competences}

\section{and Special Powers}

The remit of these specialised agencies is usually broader that of conventional bodies (police, public prosecutors, judges), both in terms of strategy (as they have a mixture of preventive and repressive competences) and in terms of their universe of action. The operational definition of corruption should not be limited to one or two types of crime in the criminal code. The agency's mission requires the fight against corruption to go beyond the legal and criminal provisions in force. The agency should also target practices and behaviours that, while not actually against the law, are ethically reprehensible. An ACA should also suggest that the legislators update the criminal code to keep up with the social evolution of the phenomenon. Corruption as a social phenomenon is always more dynamic than its penalization. Although this sounds well but practical experience has shown that a more concise and focused ACA will do better that a multifunctional one. This is supported by the averment attributed to the again, the immediate past chairman that says

"This year alone we recorded over two hundred convictions in various courts across the country but they are mostly advance fee fraud, we have the yahoo yahoo, we have the commercial cases, we have the executives of financial institutions that are involved in currency trafficking. The cases that most people are interested in its conclusion are those before the Supreme Court (Daily post 2012).

\section{d. Long-term Sustainability}

The sustainability of anti-corruption agencies is another of their defining traits. Few of them in fact have viability and their durability over time is merely the result of the capacity that the institutions demonstrate in resisting their inevitable collapse. Without an existence proven over time, the definition of an anticorruption agency is no more than a legal euphemism.

\subsection{Theoretical framework}

This study is conducted within the context of structural functional theory attributed to the work of Gabriel Almond, a theory that became so popular in the $60 \mathrm{~s}$. This theory suggests functional specification of a designate structure established for a particular set of activities. This goes to mean that a set of roles prescribed for an agency as justifications for its existence. The operational powers of such structure therefore flow from these very purposes. The EFCC is an agency (structure) 
of government established to fight a specific form of corruption derived from it name, the Economic and Financial Crimes commission. This is to say that the commission is saddled with the function of fighting financial crimes and related offences. The legal space and powers of its operations should be adequate to allow operational success in that direction. This structural functional theory provides a theoretical clue for an assessment of EFCC to determine the latitude of legal wherewithal it enjoys for its operations. For structural functionalism, the question is what a structure does within the political system. This is to understand what is expected of the structure to do and the actual. In the same token, EFCC is a structure established on the expectations to address the menace of financial crimes within certain legal space. The actual performance and empirical results achieved is to be viewed against the expected while paying attention to the powers defining its operations..

\subsection{Methodology}

This is a survey research that seeks to determine the appropriateness and the legal space allow for the EFCC to operate for optimal results. The research is conducted in Nigeria covering the six geopolitical zones and the Federal Capital Territory. The researcher utilised optimally the primary data sourced through administration of a set of structured questionnaire patterned along the likert scale system which contain questions drew from the research questions. This is in addition to a critical content analysis of documented information from the Nigerian dailies and relevant documents regarding the operations of the EFCC. Only the literate adult population were considered to be the target of study, this is due to the complexity and sensitivity of the subject of research. No doubt the subject of consideration here requires an informed mind to be able to provide insightful and policy related information. Of the over 160 million population (National Population Commission, 2006) only 738 were sampled for the study after careful selection processes were used across the six geopolitical zones in Nigeria. The data were also analysed with the aid of tables and percentage for easy understanding. This was thereafter followed with an inferential statistical technique for precision and clearer direction of results.

\subsection{Research Findings}

Discussion on the research findings will be guided by the research questions defined in the introductory section. The research question is stated as:

How appropriate and adequate is the legal framework within which the EFCC operates?

To answer this question, the mean response to the questions on section two i.e. legal frameworks, was subjected to a cross tabulation analysis and is presented in tables 1.1.1A below.

The decision rule for testing the data in this section is given as;

$5=$ Very appropriate, $4=$ Appropriate, 3 = Undecided, 2 = inappropriate, 1 = very inappropriate

\section{Result interpretation:}

From the result presented in table 5.3.3a above, it is observed that the mean scores of items 1 to 8 i.e., the Law establishing the EFCC has not provided it with adequate powers of prosecution in fighting financial crimes (3.74). The law on the limit of foreign currencies to be transferred cannot be sufficiently enforced/monitored by the EFCC (3.78). The legal instrument against drugs and narcotics as provided for by the act is operationally not strong to ensure the effectiveness of the EFCC (3.49). The EFCC cannot adequately ensure compliance of the daily cash limit to be received or paid as provided for by the prohibition act (2006), the areas of crime covered by the EFCC 
Table 1.1A: How appropriate and adequate is the legal framework within which the EFCC operates?

\begin{tabular}{|c|c|c|c|c|c|c|c|c|c|}
\hline \multirow[b]{2}{*}{ Items } & \multirow[b]{2}{*}{ STATEMENT } & \multicolumn{5}{|c|}{ Responses } & \multirow[b]{2}{*}{ Total } & \multirow[b]{2}{*}{ FX } & \multirow{2}{*}{$\begin{array}{c}\text { Mean } \\
\text { Score } \\
\bar{X}\end{array}$} \\
\hline & & $\begin{array}{l}(5) \\
\text { SA }\end{array}$ & $\begin{array}{c}(4) \\
A\end{array}$ & $\begin{array}{l}\text { (3) } \\
U\end{array}$ & $\begin{array}{l}(2) \\
D\end{array}$ & $\begin{array}{l}(1) \\
\text { SD }\end{array}$ & & & \\
\hline 1. & $\begin{array}{l}\text { The Law establishing the } \\
\text { EFCC has not provided } \\
\text { it with adequate powers } \\
\text { of prosecution in fighting } \\
\text { financial crimes }\end{array}$ & $\begin{array}{l}279 \\
37.8\end{array}$ & $\begin{array}{c}180 \\
24.4\end{array}$ & $\begin{array}{c}103 \\
14.0\end{array}$ & $\begin{array}{c}157 \\
21.3\end{array}$ & $\begin{array}{c}19 \\
2.6\end{array}$ & $\begin{array}{l}738 \\
100\end{array}$ & 2757 & 3.74 \\
\hline 2. & $\begin{array}{l}\text { The law on the limit of } \\
\text { foreign currencies to be } \\
\text { transferred cannot be } \\
\text { sufficiently enforced/ } \\
\text { monitored by the EFCC }\end{array}$ & $\begin{array}{c}196 \\
26.6\end{array}$ & $\begin{array}{c}314 \\
42.5\end{array}$ & $\begin{array}{c}116 \\
15.7\end{array}$ & $\begin{array}{c}93 \\
12.6\end{array}$ & $\begin{array}{c}19 \\
2.6\end{array}$ & $\begin{array}{l}738 \\
100\end{array}$ & 2789 & 3.78 \\
\hline 3. & $\begin{array}{l}\text { The legal instrument } \\
\text { against drugs and } \\
\text { narcotics as provided for } \\
\text { by the act is operationally } \\
\text { not strong to ensure the } \\
\text { effectiveness of the EFCC }\end{array}$ & $\begin{array}{l}129 \\
17.5\end{array}$ & $\begin{array}{l}289 \\
39.2\end{array}$ & $\begin{array}{c}165 \\
22.4\end{array}$ & $\begin{array}{c}127 \\
17.2\end{array}$ & $\begin{array}{l}28 \\
3.8\end{array}$ & $\begin{array}{l}738 \\
100\end{array}$ & 2574 & 3.49 \\
\hline 4. & $\begin{array}{l}\text { The EFCC cannot } \\
\text { adequately ensure } \\
\text { compliance of the daily } \\
\text { cash limit to be received or } \\
\text { paid as provided for by the } \\
\text { prohibition act, } 2006\end{array}$ & $\begin{array}{c}194 \\
26.3\end{array}$ & $\begin{array}{c}239 \\
32.4\end{array}$ & $\begin{array}{c}139 \\
18.8\end{array}$ & $\begin{array}{c}124 \\
16.8\end{array}$ & $\begin{array}{l}42 \\
5.7\end{array}$ & $\begin{array}{l}738 \\
100\end{array}$ & 2632 & 3.57 \\
\hline 5. & $\begin{array}{l}\text { The areas of crime } \\
\text { covered by the EFCC as } \\
\text { provided for by the law } \\
\text { is much for the EFCC } \\
\text { that some crimes are not } \\
\text { monitored }\end{array}$ & $\begin{array}{l}215 \\
29.1\end{array}$ & $\begin{array}{c}253 \\
34.3\end{array}$ & $\begin{array}{c}135 \\
18.3\end{array}$ & $\begin{array}{c}84 \\
11.4\end{array}$ & $\begin{array}{l}51 \\
6.9\end{array}$ & $\begin{array}{l}738 \\
100\end{array}$ & 2706 & 3.67 \\
\hline 6. & $\begin{array}{l}\text { EFCC should focus more } \\
\text { on financial crimes, fraud } \\
\text { and advance fee fraud only }\end{array}$ & $\begin{array}{l}320 \\
43.4\end{array}$ & $\begin{array}{c}238 \\
32.2\end{array}$ & $\begin{array}{l}74 \\
10\end{array}$ & $\begin{array}{c}91 \\
12.3\end{array}$ & $\begin{array}{c}15 \\
2\end{array}$ & $\begin{array}{l}738 \\
100\end{array}$ & 2968 & 4.03 \\
\hline 7. & $\begin{array}{l}\text { The Nigerian court system } \\
\text { has frustrated the efforts } \\
\text { of the EFCC through } \\
\text { delays and incessant } \\
\text { injunctions }\end{array}$ & $\begin{array}{c}270 \\
36.6\end{array}$ & $\begin{array}{l}307 \\
41.6\end{array}$ & $\begin{array}{c}85 \\
11.5\end{array}$ & $\begin{array}{l}54 \\
7.3\end{array}$ & $\begin{array}{c}22 \\
3\end{array}$ & $\begin{array}{l}738 \\
100\end{array}$ & 2960 & 4.01 \\
\hline 8. & $\begin{array}{l}\text { The senior legal counsels } \\
\text { usually connive with } \\
\text { the judges to subvert/ } \\
\text { manipulate judgements in } \\
\text { favour of their client }\end{array}$ & $\begin{array}{l}225 \\
30.5\end{array}$ & $\begin{array}{c}253 \\
34.3\end{array}$ & $\begin{array}{c}146 \\
19.8\end{array}$ & $\begin{array}{c}80 \\
108\end{array}$ & $\begin{array}{l}34 \\
4.6\end{array}$ & $\begin{array}{l}738 \\
100\end{array}$ & 2767 & 3.75 \\
\hline
\end{tabular}

as provided for by the law is much for the EFCC that some crimes like in the casino operations, drugs and narcotics, use of supernatural powers, etc. received less attention (3.67). EFCC should focus more on financial crimes, fraud and advance fee fraud only (4.03). The Nigerian court system has frustrated the efforts of the EFCC through delays and incessant injunctions (4.01). The senior 
legal counsel usually connive with the judges to subvert/manipulate judgements in favour of their clients (3.75) are; 3.74, 3.78, 3.49, 3.57, 3.67, 4.03, 4.01 and 3.75 respectively.

The grand mean score across the eight items was computed as 3.76 , which are approximately 4.0. This means that the overall response to the questions on this section is not appropriate and adequate. This implies that the legal framework within which the EFCC operates is not adequate and appropriate.

\subsection{Conclusion and Recommendations}

The relevance and importance of Anti -corruption Agency in the management and liberation of human society from the shackles of corruption and it evil repercussion can never be over stretched. It can be argued on sustainable instance that corruption is the mother of all evils and social problems; in fact it fuels the underdevelopment of many third world countries. The Nigerian case is to an extent even more worrisome as all efforts to rid the country of this ugly monster during and after military regimes seem fruitless. It is even more heartbreaking if attention is paid on the expectations placed on the EFCC given the apparent vigour and impression it has attracted from the general public and the international community. It is believed that the EFCC is well positioned amongst all other sister Ant graft agencies, especially drawing from the failure of the past efforts by previous government. This no doubt attracted research attentions from inside and outside academia to understand why EFCC cannot do more than it has achieved. This paper is one of such concerns. It is observed therefore that it is not just enough to have resources of both human and financial base but a clear mandate with precise target accompanied with adequate powers and space will do more good for a government and its people rather than having an agency with a bogus set of objectives and multi faceted mandates.

By virtue of recommendation therefore, it is a mandatory requirement to streamline the functions of the EFCC to financial crimes and redefine its powers to fit into these functions. Secondly, there is need for a separate and specialised court or tribunal to handle financial crimes to avoid the incessant delays associated with the regular courts. Thirdly, the agency needs more powers that will enable it prosecute an accused person effectively. Fourthly, The Nigerian judicial council should put a check on continuous basis the activities of the counsels and judges with a view to ensuring compliance to their professional ethics and punish defaulters with tendentious corruption traits.

\section{Reference}

Almond, Gabriel (ND), Structural Functionalism, Retrieved from www.political science notes. com on $20^{\text {th }}$ November, 2015.

Andvig, Jens Chr., odd-helge F., Amudsen T. and Soreid T. (2001), Corruption: A Review of Contemporary Research. Norway, Michelson Institute.

Daily Trust (2012), Court Frees Halliburton Bribe Suspects After Sloppy Prosecution by EFCC, Tuesday March 27, 2012, Front Page and pg 5.

Daily Post (2012), Nigerian Banks Sabotaging Anti-corruption War, Says EFCC Chief. Retrieved From http//www.dailypost.com.ng/2012/18/12 on $9^{\text {th }}$ September, 2012.

Federal Republic of Nigeria (2006), Population and Housing Census, Priority Tables, Volume 1 Lagos: Federal Government Press. 
Heilbrunn, John R. (2004), Anti-Corruption Commissions: Panacea or Real Medicine to Fight Corruption? Washington, The World Bank.

Meagher, P. and C. Voland (2006), Anti-corruption Agencies, United States Agency for International Development, University of Maryland-IRS Centre.

\title{
Экономические и финансовые преступления и борьба с коррупцией \\ в Нигерии: оценка правовой базы
}

\author{
Хассан Саид Умар, Касим Умар \\ Университет Абуджи \\ P.M.B 118, Permanent Site, Airport Road, Abuja-FCT
}

Опасность коррупчии и борьба с ней во всем мире являются основной заботой многих ученых и государственных структур, в особенности в странах третьего мира. Существование антикоррупционных агентств во всех странах подтверждает данное мнение. Некоторые из таких структур преуспели в странах, где они ведут свою деятельность, в то время как другие все еще пытаются совладать с динамикой и сложностями данного явления, подбирая надежные методы для борьбы с коррупиией. В данной статье дана оценка отномения нигерийцев к эффективности работы Комиссии по экономическим и финансовым преступлениям с целью определения компетентности и соответствия действий Комиссии. В работе исследовались первоисточники и вторичные источники данных. Основываясь на теории структурнофункиионального анализа, автор делает вывод о том, что Комиссии недостает обвинительных функиий. Кроме того, Комиссия не может эффективно отслеживать соблюдение лимита перевода валюты (10 000 долларов США) и лимита на локальные операции с наличными. Судебная система Нигерии также срывает попытки Комиссии эффективно выполнять свои функции в дополнение к неуправляемому поведению некоторых старших адвокатов, которые зачастую находятся в сговоре с судьями, подрывая основы правосудия. Таким образом, в статье утверждается, что Комиссии приходится работать в неблагоприятных правовых условиях, что в значительной степени мешает ее эффективности. Кроме того, предлагается создание отдельного суда со специально подготовленными судьями, специализирующимися на финансовых преступлениях, ограничивая их сферу ответственности рассмотрением дел Комиссии по экономическим и финансовым преступлениям.

Ключевые слова: коррупци, Комиссия по экономическим и финансовым преступлениям, функиия, правовая база.

Научная специальность: 22.00.00 - социологические науки, 23.00.00 - политология. 